\title{
Nilai-nilai Filosofis Didaktis, Humanistis, dan Spiritual dalam Kesenian Tradisional Macapat Masyarakat Bali
}

\author{
I Made Suarta \\ Fakultas Pendidikan Bahasa dan Sastra, IKIP PGRI Bali
}

madesuarta62@gmail.com

Penelitian ini bertujuan untuk memahami nilai-nilai filosofis didaktis, humanistis, dan spritual yang terkandung di dalam kesenian tradisional macapat pada masyarakat Bali. Telaah kesenian tradisional macapat dapat dikatakan sebagai aktivitas kebudayaan yang mempunyai fokus penting untuk mengetahui identitas masyarakat, partisipasi, serta eksistensi suatu peradaban masyarakat. Pada dasarnya, tembang macapat tidak berbicara dengan dirinya sendiri dan menyuarakan dirinya sendiri. Ia berhadapan dan menyuarakan kompleksitas kehidupan kultural masyarakat Bali. Oleh karena itu, macapat mengandung nilai-nilai filosofis (didaktis, humanistis, dan spiritual) di dalamnya, sehingga menjadikannya sebagai wacana sosial dan terlibat secara tidak langsung dalam dinamika interaksi sosio-kultural pada masyarakat Bali. Penelitian ini menggunakan rancangan penelitian deskriptif kualitatif yang beranjak dari pendekatan fungsional terhadap seni bersastra tradisional Bali. Sumber data dalam penelitian diklasifikasikan menjadi dua, yaitu sumber data primer (sumber data yang berasal langsung dari subjek) dan skunder (sumber data berasal dari buku/ teks/ kitab/ literature). Metode pengumpulan data yang digunakan adalah observasi dan studi kepustakaan. Langkah analisis data ini dilakukan dengan menggunakan metode deskriptif kualitatif. Metode ini dilakukan dengan menggunakan beberapa langkah operasional, yaitu reduksi data, penyajian data, dan penarikan simpulan. Ketiga tahapan tersebut saling berinteraksi dan memiliki koneksi, berawal dari pengumpulan data dan berakhir pada penarikan simpulan. Nilai didaktis yang terdapat di dalam tembang macapat mengajarakan manusia tentang pentingnya pendidikan dan ilmu pengetahuan untuk menjadi manusia yang bermoral dan beretika. Ajaran humanis dalam tembang macapat memberikan pedoman dan petunjuk kepada manusia bahwa menjalani kehidupan di dunia harus selalu mematuhi norma-norma yang berlaku di dalam masyarakat. Gotong royong, persaudaraan, persahabatan, dan kerukunan adalah nilai-nilai humanisme yang terdapat dalam tembang macapat. Nilai-nilai spiritual yang terdapat dalam tembang macapat adalah mengajarkan manusia untuk selalu melaksanakan ajaran agama untuk mendapatkan keseimbangan sekala dan niskala.

Kata kunci : didaktis, humanistis, spritual, macapat

\section{Philosophical Values of Dictition, Humanistic, and Spirituality in Traditional Arts of Macapat Bali Society}

This study aims to understand the didactic, humanistic, and spiritual philosophical values embodied in the traditional art of macapat in Balinese society. The study of traditional arts macapat can be regarded as a cultural activity that has an important focus to know the identity of society, participation, and the existence of a civilization society. Basically, tembang macapat not speak to himself and voice himself. He confronts and voices the complexity of Balinese cultural life. Therefore, macapat contains philosophical (didactic, humanistic, and spiritual) values in it, thus making it a social discourse and indirectly involved in the dynamics of socio-cultural interaction in Balinese society. This research uses descriptive qualitative research design that moved from the functional approach to traditional Balinese literature. Sources of data in the study are classified into two, namely primary data sources (source data derived directly from subject) and secondary (source data comes from books / text / books / literature). Data collection methods used are observation and literature study. Step analysis of this data is done by using descriptive qualitative method. This method is done by using some operational steps, namely data reduction, data presentation, and conclusion drawing. These three stages interact and have a connection, starting from data collection and ending in drawing conclusions. The didactic value contained in the tembang macapat teaches people the importance of education and science to become moral and ethical human beings. Humanist teachings in tembang macapat provide guidance and guidance to humans that live life in the world must always adhere to the norms prevailing in society. Gotong royong, 
brotherhood, friendship, and harmony are the values of humanism contained in tembang macapat. Spiritual values contained in the tembang macapat is to teach people to always implement the teachings of religion to get the balance sekala and niskala.

Keywords: dictition, humanistis, spritual, macapat

Proses Review : 1 - 31 Maret 2018, Dinyatakan Lolos: 10 April 2018

\section{PENDAHULUAN}

Macapat merupakan sebuah karya sastra yang telah menjadi khazanah dari kebudayaan dan memiliki kedudukan sangat berharga dan mulia dalam kehidupan sosio-kultural masyarakat Bali. Macapat dipandang sebagai salah satu kekayaan khas sastra daerah yang lahir dari penafsiran, ekspresi jiwa yang imajinatif, dan idealisasi pengarangnya terhadap kehidupan sosial masyarakat yang dituangkan ke dalam komposisi dan struktur artistik. Sebagai suatu karya sastra daerah, macapat merupakan salah satu produk kebudayaan yang sudah mengakar secara terun-temurun dalam kehidupan masyarakat Bali, khususnya dalam bidang berkeseniaan. Kesenian macapat ini, lahir dan berkembang didasari oleh adanya motivasi, kreasi, dan ide pengarang dalam mentransformasikan nilai-nilai dan norma-norma etika, moral, dan religi kepada para generasi penerus. Dengan kata lain, kesenian tradisional macapat digunakan sebagai media pencerahan nilai-nilai kehidupan manusia yang biasanya dijadikan sebagai pedoman, baik dalam bertutur kata maupun bersikap sesuai dengan norma-norma yang berlaku di masyarakat.

Di dalam macapat, terekam berbagai perjalanan pengalaman luhur hidup manusia yang secara moral mampu mendorong suatu individu untuk berpikir dan berbuat demi pengembangan diri dan masyarakat serta mendorong munculnya kepedulian dan keterbukaan dalam pergaulan sosial. Fase-fase perjalanan kehidupan manusia yang tergambar dalam tembang macapat, dilihat dari perspektif alur dan makna yang terkandung, adalah sebuah rangkaian alur kehidupan dan keberadaan manusia (ontologi), cara menemukan hakikat hidup yang benar (epistimologi), dan sekaligus mempunyai nilai etika (aksiologi). Dalam hal ini, ketiga alur tersebut adalah kerangka yang mambangun filsafat masyarakat Bali itu sendiri menuju ketercapaian hidup yang lebih baik (Moehanto, 1987). Gambaran perjalanan pengalaman manusia tersebut dapat direpresentasikan sebagai pengetahuan atau pendidikan yang berupa wejangan-wejangan/ petuah-petuah/ "'pitutur" melalui syair-syair untuk para generasi penerus agar dapat hidup harmonis dan berdampingan dalam masyarakat atau suatu komunitas. Nilai yang terkandung di dalam kesenian macapat juga mampu memberikan kehalusan jiwa dan menyadarkan manusia akan kewajibannya sebagai makhluk tuhan yang pada hakikatnya harus selalu berbakti dan menjalankan segala amanat yang dikaruniai dalam kehidupan. Selain itu, macapat juga mampu mendorong penciptaan masyarakat yang beradab, memanusiakan manu- sia, memperkenalkan keuniversalan sifat manusia, melatih kecerdasan emosional, dan mempertajam penalaran.

Sesungguhnya, kesenian tradisional macapat tidak hanya dapat dipandang sebagai sebuah produk kebudayaan yang sekadar menawarkan hiburan dan estetika semata. Macapat juga dapat dimanfaatkan sebagai media penanaman cinta kasih kepada sesama dan sang pencipta serta mendidik manusia menuju keterwujudan akhlak dan budi yang luhur, sehingga tercapai ketentraman dan kedamaian jiwa. Macapat juga kerap difungsikan sebagai media komunikasi untuk mengaktualisasikan kebutuhan manusia sebagai makhluk sosial. Bahkan di suatu kesempatan, macapat digunakan untuk melakukan sindiran maupun kritik sosial oleh kaum cendekiawan/ seniman kepada para penguasa/ pemerintah.

Di samping itu, tembang macapat dinilai sebagai salah satu metode pengajaran hidup para leluhur terhadap generasi sesudahnya. Dalam tetembang macapat ini diajarkan tentang hidup dan perilaku kehidupan yang bertujuan untuk memberikan pelajaran yang isinya merupakan pengetahuan dan pelajaran tentang hidup. Ajaran hidup tersebut bersifat manusiawi, jika ajaran tersebut diterapkan dalam kehidupan masyarakat, yang bersangkutan akan menemukan ketentraman jiwa yang membawanya pada ketentraman hidup, karena kesenian ini sarat dengan falsafah. Selain itu, kesenian tembang macapat juga mengandung nilai-nilai filsafat di mana ajarannya bersifat kausal untuk segala usia, dari anak-anak hingga dewasa. Oleh karena itu, dapat dikatakan bahwa sastra tradisional macapat memiliki fungsi yang multidimensional, artinya kedudukan macapat sebagai salah satu produk sastra daerah mempunyai macam-macam fungsi yang dapat dimanfaatkan dalam kehidupan manusia, khususnya masyarakat Bali.

Macapat dalam konteks sastra daerah Bali merupakan kekayaan budaya yang eksistensinya sangat bergantung pada masyarakat pendukungnya. Dewasa ini perkembangan macapat pada umumnya bisa dikatakan masih belum memuaskan karena kesenian ini kurang diminati oleh kaum pemuda, meskipun ada akan tetapi jumlahnya relatif sedikit. Eksistensi macapat masih mengandalkan seniman-seniman tua atau manula yang secara alamiah tidak akan selamanya ajek. Pengaruh globalisasi merupakan salah satu hal yang menyebabkan tergesernya nilai-nilai kebudayaan, baik berupa pola pergaulan yang berpangkal dari pemikiran masyarakat itu sendiri maupun dari luar masyarakat sehingga pergeseran sastra daerah, khusunya macapat mulai tampak. Hal ini sesuai dengan pandangan 
Moehanto (1987) yang menyatakan bahwa macapat adalah bentuk seni yang bersifat komunal, di mana ia lahir, hidup, dan berkembang oleh masyarakat, maka perkembangan dan pasang surutnya pun juga mengikuti dinamika yang terjadi di masyarakat.

Beberapa penelitian yang berkaitan dengan kajian kesenian tradisional tembang macapat telah dilakukan oleh beberapa peneliti di antaranya, Haryatmo, dkk (2014) dengan judul penelitian Macapat Modern dalam Sastra Jawa: Analisis Bentuk dan Isi. Penelitian ini mencoba menyingkap karakteristik bentuk macapat modern dalam sastra Jawa dan melihat sejauh mana para pengarang mengikuti konvensi yang berlaku dalam tembang macapat. Selain itu, juga melihat sejauh mana tema yang digunakan dalam macapat mengandung berbagai fenomena kehidupan. Setiyadi (2010) dalam Wacana Tembang Macapat Sebagai Pengungkapan Sistem Kognisi dan Kearifan Etnik juga berusaha melihat struktur dan karakteristik wacana tembang macapat, serta menyingkap sistem kognisi dan kearifan lokal etnik Jawa.

Runik (2011) dalam Revitalisasi Karakter Bangsa Melalui Pendidikan Kewarganegaraan dengan Pengembangan Budaya Lokal: Studi Kasus Budaya Macapat menyatakan bahwa anggota masyarakat mendukung dan menganggap penting pembangunan karakter bangsa dengan melakukan pembinaan nilai dan sikap toleransi, gotong-royong, sopan santun, dan cinta tanah air melalui tembang macapat. Selain itu, dikatakan pula bahwa budaya macapat juga masih relevan sebagai sarana dan wahana dalam pembangunan karakter bangsa. Di rumah maupun di masyarakat pembangunan karakter bangsa dilakukan dengan menggunakan pendekatan interventif dan habituasi yang meliputi pemberian pemahaman, memberikan keteladanan, membangun kebersamaan dan komunikasi.

Hampir serupa dengan Runik (2011), Navitasari (2013) dalam Penguatan Karakter Bangsa Melalui Pembinaan Budaya Macapat juga mempunyai tujuan untuk mengungkap kontribusi kandungan nilai dari tembang macapat dalam menguatkan karakter bangsa. Secara subtansial Navitasari (2013) berupaya mengkaji efek nilai yang bisa disumbangkan dalam tembang macapat dan sejauh mana kegunaannya bagi pengembangan kemampuan karakter bangsa dalam diri suatu individu.

Berdasarkan pemikiran-pemikiran di atas, untuk melestarikan kesenian daerah macapat maka dianggap perlu diadakan penelitian tentang Analisis Nilai-nilai Filosofis Didaktis, Humanistis, dan Spiritual dalam Kesenian Tradisional Macapat pada Masyarakat Bali, agar nilai-nilai yang terkandung dalam macapat dapat terus diposisikan sebagai karya sastra yang bernilai tinggi dan adiluhur. Tujuan dan fokus penelitian ini adalah untuk mengkaji nilainilai filosofis didaktis yang terkandung dalam kesenian tradisional macapat, nilai filosofis humanistis yang ter- kandung dalam kesenian macapat, dan nilai filosofis spiritual yang terkandung dalam kesenian tradisional macapat pada masyarakat Bali.

Tembang macapat sejauh ini dipersepsikan oleh masyarakat pada umumnya sebagai "macane papat-papat", yang diinterpretasikan dalam bahasa Indonesia menjadi melagukan macapat itu pemenggalannya harus empat-empat. Definisi ini sesungguhnya belum sepenuhnya dapat digunakan sebagai acuan, mengingat dalam sebuah tembang macapat ada beberapa kalimat yang tidak mungkin pemenggalannya empat-empat, karena akan mengaburkan arti atau makna kalimat itu sendiri. Definisi lain yang berhubungan dengan macapat, mengartikan macapat sebagai membaca dengan tepat. Kata tepat di sini mengandung banyak pengertian, meliputi tepat pemenggalannya, tepat/ konsisten dalam penggunaan nada, tepat artikulasinya, serta tepat penerapan karakter lagunya. Tepat pemenggalannya bahwa dalam membawakan macapat cara memenggal kalimat atau kata lagu dalam setiap baris harus memperhatikan arti dari kalimat lagu, tidak boleh sembarangan memenggal kalimat atau kata. Tepat/ konsisten dalam penggunaan nada, bahwa dalam membawakan macapat, baik itu menggunakan atau tidak menggunakan tuturan gamelan harus dilagukan secara konsisten dengan mengacau pada laras gambelan. Tepat artikulasi, bahwa dalam membawakan macapat harus dengan mengucapkan ejaan kata dengan benar. Salah dalam artikulasi akan merubah arti dari kalimat yang dimaksud. Tepat penerapan karakter lagu, bahwa dalam setiap tembang macapat mempunyai karakter sendiri-sendiri, untuk itu dalam membawakannya harus disesuaikan dengan karakter sesungguhnya. Ada beberapa jenis macapat yang lumrah/ populer digunakan oleh masyarakat Bali, jenis macapat tersebut sering disebut dengan pupuh. Secara harfiah pupuh memiliki pengertian lagu yang terikat oleh banyaknya suku kata dalam satu bait, jumlah larik, dan permainan lagu. Dalam masyarakat Bali pupuh terdiri atas, Maskumambang, Mijil, Sinom, Ginanti, Ginada, Semarandana, Dangdang, Durma, Pangkur, dan Pucung.

Penelitian ini memiliki kontribusi sebagai sumber rujukan bagi pemerintah untuk mengupayakan pelestarian kesenian tradisional macapat yang merupakan kesenian khas daerah Bali dengan melakukan sosialisasi kepada masyarakat, khususnya anak-anak muda bahwa kesenian macapat selain sebagai sebuah seni pertunjukkan olah suara tetapi juga dapat digunakan sebagai media pendidikan, agama, dan sosial/ pergaulan. Penelitian juga dapat membangun kesadaran para praktisi seni macapat di Bali bahwa kesenian macapat tidak hanya cukup untuk dilantunkan sebagai media pelipur lara dan pemenuhan kebutuhan individual semata, melainkan perlu juga diresapi, dihayati, dan dipahami secara mendalam makna dan nilai-nilai yang terkandung di dalamnya. Hal ini perlu dilakukan untuk memberikan pencerahan kepada khalayak bahwa kesenian macapat juga dapat digunakan sebagai saran pembelajaran diri yang berkaitan dengan kehidupan sosial dan spiritual, 
sehingga secara tidak langsung masyarakat awam tertarik untuk mempelajari, menekuni, atau bahkan mempraktikan keseniaan ini dalam acara-acara tertentu. Dengan demikian, eksistensi kesenian macapat akan semakin menggeliat ke permukaan di tengah-tengah lesunya peminat kalangan pemuda di era modern saat ini. Dalam konteks pendidikan karakter, hasil penelitian berkontribusi dalam upaya penyediaan sumber atau referensi dalam rangka menanamkan nilai-nilai luhur, seperti nilai didaktis, humanistis, dan spiritual yang terkandung di dalam keseniaan macapat kepada para peserta didik. Sehingga mampu membangun budi pakerti/ akhlak yang mulia dalam diri peserta didik dengan tujuan menciptakan bangsa yang bermartabat. Penelitian ini juga dapat menumbuhkan kesadaran bagi kaum pemuda di Bali bahwa kesenian macapat bukanlah sekadar aktivitas bernyanyi/ metembang semata, lebih daripada itu kesenian macapat memiliki manfaat dan nilai-nilai pendidikan yang sangat tinggi, baik berupa nasihat-nasihat, ajakan ataupun anjuran yang tentunya bersifat positif. Mengingat besarnya nilai-nilai kehidupan yang dapat disumbangkan, tentunya secara perlahan-lahan akan tumbuh kesadaran dalam diri pemuda Bali untuk aktif menekuni kesenian macapat, sehingga kesenian ini nantinya dapat berkembang secara masif dan ajek sebagai jati diri masyarakat Bali.

\section{METODE PENELITIAN}

Penelitian ini merupakan suatu penelitian yang beranjak dari pendekatan fungsional terhadap seni bersastra tradisional Bali. Dalam hal ini, seni macapat dapat dikatakan sebagai suatu aktivitas apresiasi sastra dalam masyarakat Bali yang dilatari oleh faktor-faktor sosial (etika, tradisi, agama, dan sebagainya). Beranjak dari pandangan tersebut, penelitian ini tergolong ke dalam penelitian deskriptif kualitatif. Penelitian kualitatif digunakan sebagai prosedur pengidentifikasian dan pendeskripsian fenomena yang terjadi berdasarkan keadaan senyatanya, karena tergolong ke dalam penelitian jenis kualitatif, penelitian ini memiliki ciri-ciri sebagai berikut: (1) kontekstual, penelitian dilakukan dalam konteks aktivitas berkesenian macapat dan tindakan normal subjek, (2) kolaboratif, melibatkan partisipan subjek dan triangulasi pakar di dalam penyimpulan data, (3) interpretatif, menggunakan analisis berdasarkan pandangan dan referensi yang relevan, bukan analisis statistik, (4) interaktif, memiliki keterkaitan antara masalah penelitian, pengumpulan data, dan interpretasi data, dan (5) peneliti sebagai human instrument / instrumen kunci.

Data dalam penelitian ini adalah nilai didaktis, humanistis, dan spiritual yang terkandung dalam kesenian tradisional macapat pada masyarakat Bali. Sedangkan sumber data dalam penelitian ini dikategorikan menjadi dua macam yaitu, sumber data primer dan sekunder.

Sumber data primer adalah sumber yang secara langsung berasal pihak pertama, artinya data diperoleh secara langsung dari subjek melalui metode observasi. Sumber data primer bersumber dari beberapa subjek yang akan diamati/ direkam di antaranya, budayawan/ praktisi seni (yang biasa macapat/ metembang). Dalam hal ini, tiap-tiap individu diberikan kesempatan yang sama untuk dijadikan sampel asalkan memenuhi kriteria yang sudah ditentukan sebagai berikut:

Berjenis kelamin pria atau wanita.

subjek merupakan masyarakat asli dari Bali yang bisa berkesenian macapat.

Berusia antara 35-60 tahun (tidak pikun serta sehat jasmani dan rohani).

Minimal berpendidikan SD/ tahu membaca.

Sumber data sekunder adalah sumber data yang berasal dari kepustakaan, seperti literature/ buku antologi/ teksteks yang memuat tentang karya seni macapat masyarakat Bali. Data ini akan melengkapi data primer yang diperoleh sebelumnya.

Metode pengumpulan data yang digunakan ada dua, yaitu metode observasi dan studi kepustakaan. Metode observasi digunakan agar dapat secara jelas mendeskripsikan ob$\mathrm{jek} /$ masalah yang sedang diteliti. Metode observasi yang digunakan adalah metode observasi partisipasi pasif. Artinya, peneliti tidak terlibat langsung dalam kegiatan narasumber, cukup melakukan pengamatan dan melakukan pencatatan tentang data yang akan dikumpulkan. Teknik perekaman ini digunakan untuk melengkapi data yang tidak diperoleh dari pengamatan secara langsung. Selain itu, teknik perekaman digunakan untuk menghindari kelalaian dalam mencatat. Alat yang digunakan dalam pengambilan data berupa rekaman adalah video-visual. Video-visual digunakan untuk merekam aktivitas macapat/ matembang yang dilakukan oleh narasumber secara langsung.

Untuk melengkapi data yang diperoleh melalui observasi dengan teknik perekaman, digunakan juga metode studi kepustakaan. Metode studi kepustakaan ini merupakan metode pengumpulan data yang dilakukan dengan cara mencari atau mengambil data dari buku-buku, kitab-kitab, literature, atau teks-teks kesusastraan. Metode ini digunakan dengan pertimbangan bahwa akan memudahkan peneliti menganalisis nilai-nilai didaktis, humanistis, dan spiritual dari tembang tradisional macapat yang dimuat dalam bentuk lontar-lontar, buku antologi, atau teks-teks kesusastraan lainnya. Data macapat tersebut kemudian dianalisis berdasarkan permasalahan yang dikaji menggunakan teori-teori yang relevan.

Instrumen utama dalam penelitian ini adalah peneliti sendiri. Dalam hal ini, peneliti yang mengumpulkan, mengidentifikasi, menyeleksi, dan menganalisis data. Peneliti dapat dikatakan sebagai human instrument. Artinya, penelitilah yang memikul banyak peran dalam mengumpulkan, menyeleksi, dan menafsirkan data. Sebagai instrumen kunci, peneliti dapat dikatakan sebagai bagian dari 
masyarakat Bali dan mempunyai pengetahuan tentang tradisi berkesenian macapat. Dengan berbekal pengetahuan tentang tradisi atau budaya berkesenian macapat, relatif akan memudahkan peneliti menginterpretasikan data tentang nilai-nilai didaktis, humanistis, dan spiritual yang terkandung dalam kesenian tradisional macapat. Di samping peneliti sebagai istrumen kunci, digunakan juga instrumen-istrumen penunjang untuk menutupi kekurangan yang dialami dalam pengumpulan data. Dengan demikian, digunakanlah media-media seperti alat/video perekam dan literature/ buku antologi/ teks-teks tentang karya seni macapat.

Langkah analisis data ini dilakukan dengan menggunakan metode deskriptif kualitatif. Metode ini dilakukan dengan menggunakan beberapa langkah operasional, yaitu reduksi data, penyajian data, dan penarikan simpulan. Ketiga tahapan tersebut saling berinteraksi dan memiliki koneksi, berawal dari pengumpulan data dan berakhir pada penarikan simpulan.

\section{HASIL DAN PEMBAHASAN}

\section{Nilai Didaktis Tembang Macapat}

Nilai didaktis/ pendidikan diartikan sebagai kupasan secara konseptual terhadap kenyataan-kenyataan kehidupan manusia baik disadari maupun tidak disadari. Kesadaran akan konsep tersebut menunjukkan bahwa manusia sebagai makhluk budaya yang salah satu tugas kebudayaan itu tampak pada proses pendidikan. Nilai didaktis di dalam tembang macapat mengandung ajaran-ajaran yang mendidik dan menuntun manusia agar sesuai dengan norma-norma kesopanan yang berlaku di dalam pergaulan masyarakat etnik Bali. Macapat sebagai suatu karya sastra yang artistik secara konseptual dapat dijadikan landasan bersikap, baik bagi kebutuhan personal maupun kolektif guna terwujudnya karakter positif masyarakat Bali. Nilainilai didaktis yang terkandung dalam tembang macapat, di antaranya adalah kejujuran, kedisiplinan, kerja keras, bertanggung jawab, dan kasih sayang. Di bawah ini, disajikan beberapa data tembang macapat disertai dengan hasil analisisnya menggunakan teori didaktis.

\section{Pupuh Ginada \\ Ne mangkin bapa ngindayang, artin satya ne pang uning, ento sila kaping tiga, melahang cening mangrungu, Sang Satya tan nahan bobab, jujur sahih, makadi satya wacana.}

Setelah digali secara mendalam Pupuh Ginada di atas mengandung nilai didaktis tentang nasihat orang tua kepada anaknya agar memupuk sifat-sifat kejujuran yang harus dilaksanakan dalam setiap pergaulan, baik dalam keluarga maupun masyarakat. Masyarakat Hindu Bali mengenal is- tilah panca satya, yaitu lima kejujuran yang harus dilaksanakan oleh manusia agar tercipta keterbukaan sebagai upaya menghindarkan diri dari konflik personal maupun interpersonal. Kejujuran merupakan representasi dari kebenaran yang harus dibiasakan sejak dini agar tercipta sebuah habitut (kebiasaan yang positif) dalam diri manusia, sehingga kedamaian dan ketentraman alam sekala dan niskala adalah keniscayaan. Panca satya terdiri atas lima bagian, yaitu satya wacana (jujur pada perkataan), satya hredaya (jujur pada hati nurani), satya laksana (jujur mengakui segala kebenaran maupun kesalahan dari perbuatan), satya mitra (setia/ jujur kepada sahabat), dan satya semaya (jujur/ setia pada janji). Salah satu sikap jujur/ satya yang tertuang secara tekstual dalam Pupuh Ginada di atas satya wacana (jujur pada perkataan/ ucapan). Nilai didaktis tentang satya wacana memberikan kita petunjuk bahwa dalam keadaan, situasi, dan kondisi apa pun harus selalu mengutamakan kejujuran dalam perkataan. Setiap perkataan yang telah diujarkan harus dipertanggungjawabkan kebenarannya agar tidak merugikan diri sendiri maupun orang lain.

\section{Pupuh Ginanti \\ Nanak bagus sang annulus, malih bapa memanjangin, sang ngamong Bharmacarya, teleb ngamong budhi hening, bersih galang twara samar, gemet ngemit suklan hati.}

Nilai didaktis yang bisa didapatkan dalam pupuh Ginanti di atas adalah tentang kasih sayang seorang guru rupa$k a$ ataupun guru pengajian kepada anak/ muridnya agar dapat mengamalkan ilmu yang dimiliki dengan baik. Nasihat-nasihat sang guru kepada muridnya merupakan suatu kewajiban yang harus dilakukan karena tugas guru tidak hanya menjadi pendidik tetapi juga pembimbing/ konselor agar dapat menuntun anak didik kea rah pencapaian akhlak yang mulia. Secara tekstual, tembang macapat di atas dapat dimaknai bahwa seorang yang mengemban tugas sebagai pelajar haruslah memiliki hati dan pikiran yang bersih untuk mengabdikan diri kepada ilmu pengetahuan agar dapat digunakan demi kepentingan personal maupun kolektif di masyarakat. Seseorang yang sedang menjalankan tugas/ swadharma sebagai pelajar harus senantiasa tekun belajar agar memperoleh sinar ilmu pengetahuan yang terang. Dalam ajaran masyarakat Hindu Bali, manusia memiliki empat jenjang kehidupan berdasarkan rohani, waktu, umur, dan sifat yang disebut dengan $\mathrm{Ca}$ tur Asrama. Salah satu bagian dari Catur Asrama adalah brahmacari yang memiliki pengertian sebagai tahapan kehidupan menuntut ilmu. Ajaran Brahmacari menegaskan bahwa ketika manusia sedang menjalankan masa kehidupan menuntut ilmu dilarang mengumbar hawa nafsu atau berhubungan sex karena berisiko menghancurkan perjalanan pendidikan. Oleh karena itu, menjalankan masa kehidupan Brahmacari harus berdasarkan ketulusan dan 
kesucian jiwa lahir dan bhatin demi ketercapaian cita-cita. Pengetahuan/ kebenaran yang hakiki hanya bisa diperoleh/ dikuasai ketikaa manusia dengan tulus ikhlas dan berlandaskan kesucian pikiran menyerahkan diri sepenuhnya untuk ilmu pengetahuan. Dengan kata lain, ilmu pengetahuan hanya bisa dikuasai dengan baik apabila seseorang secara totalitas mempelajarinya.

\section{Pupuh Pucung \\ Eda takut, \\ ngutang tuyuh ngalih hayu, \\ buatang gemetang, \\ lautan jalanan cening, \\ koja bingung, \\ teken goda sasungglapan.}

Nilai didaktis yang dapat dipetik dalam pupuh pucung di atas adalah tentang kerja keras. Pupuh tersebut menekankan bahwa jangan takut untuk bekerja keras untuk sebuah hasil yang baik/ maksimal. Jangan juga bimbang menentukan sebuah keputusan, keyakinan adalah harga mati yang diibaratkan obor penerang jalan agar manusia tidak terjerumus pada kegelapan. Sebuah pekerjaan perlu dilakukan dengan loyalitas dan dedikasi tinggi untuk sebuah pencapaian yang maksimal. Tiada hasil yang baik jika tidak diimbangi dengan usaha dan kerja keras. Tembang macapat di atas memberikan nasihat kepada kita bahwa kerja keras dan keyakinan adalah kunci utama kesuksesan.

\section{Nilai Humanistis Tembang Macapat}

Humanisme adalah sebuah pemikiran filsafat yang mengedepankan nilai dan kedudukan manusia serta menjadikannya sebagai kriteria dalam segala hal. Humanisme telah menjadi sejenis doktrin beretika yang cakupannya diperluas hingga mencapai seluruh etnisitas manusia. Humanisme juga dapat dikatakan sebagai gerakan fundamental dengan tujuan untuk mempromosikan harkat dan martabat manusia. Sebagai pemikiran etis yang menjunjung tinggi manusia, humanisme menekankan harkat, peran, tanggung jawab menurut manusia secara esensial dalam kehidupan. Nilai humanism memandang manusia mempuyai kedudukan yang istimewa dan berkemampuan lebih dari mahluk lainya karena mempunyai rohani. Pandangan ini membuat manusia sadar kembali tentang harkat dan martabat manusia sebagai mahluk rohani. Nilai humanistis dalam tembang macapat masyarakat Bali berkaitan erat dengan kehidupan manusia secara sosial. Nilai humanisme ini dianut oleh manusia mengenai apa yang dianggap baik dan apa yang dianggap buruk. Tembang-tembang macapat sebagai suatu karya sastra yang berakar dari sosio-kultural masyarakat Bali memberikan pelajaran yang luhur tentang nilai-nilai kemanusiaan. Macapat merupakan penafsiran dan representasi pemikiran/ idealisasi pengarang. Carut-marut dari problematika yang terdapat di dalam tembang macapat adalah cerminan pengolahan realita kehidupan yang dialami oleh pengarang dan masyarakat Bali secara umum. Nilai-nilai humanistis yang diperoleh dari hasil analisis tembang macapat adalah kekeluargaan/ persaudaraan, kerukunan, gotong-royong/ tatwam asi, dan bhineka tunggal ika. Berikut ini disajikan beberapa data teks macapat disertai hasil analisisnya menggunakan teori humanistis.

\section{Pupuh Sinom \\ Ane madan Tri Mala, \\ Memotoh mamunyah malih, \\ Makadinnya wewadonan, \\ Ento tri mala kadanin, \\ Gemetang ento apikin, \\ Mangdennya tan ngardi buwut, \\ Ring somah lan nyama braya, \\ Pemerintah to makardi, \\ Nah pemuput, \\ Eda ampah makta raga.}

Nilai humanis yang terdapat dalam tembang macapat di atas adalah tentang nilai kekeluargaan dalam kehidupan bermasyarakat. Konsep kultural tentang menyama braya dalam kehidupan bermasyarakat harus didahulukan untuk menciptakan keharmonisan/ kerukunan. Dijelaskan di atas bahwa konsep menyama braya bisa dijalankan dengan baik bila manusia menghindari Tri Mala. Tri Mala dalam ajaran Hindu Bali mempunyai pengertian sebagai tiga sifat kotor yang melekat dalam jiwa manusia akibat pengaruh buruk dari nafsu yang tidak terkendali dan sangat bertentangan dengan kesusilaan. Tri Mala terdiri atas mithia hradaya (selalu berprasangka buruk kepada orang lain), mithia wacana (selalu berkata angkuh, sombong, dan selalu berkata bohong), dan mithia laksana (berprilaku tidak baik, kurang ajar, tidak beretika hingga merugikan diri sendiri dan orang lain). Menjalankan ajaran Tri Mala dalam kehidupan bermasyarakat, baik dalam organisasi banjar atau desa adat sangat diperlukan agar tidak terjadi disharmoni atau disintegrasi. Dengan demikian, musyawarah mencapai mufakat dapat tercapai bila konsep ajaran Tri Mala dapat diimplementasikan dengan kesungguhan hati.

\author{
Pupuh Durma \\ Sang Bupati sajawaning ngamong jagat, \\ taler tan telad makerti, \\ ngardi dana-punya, \\ mayadnya masih tan kirang, \\ ne sinah mangawe trepti, \\ kancan wadwa, \\ merasa sami kauripin.
}

Nilai humanisme dalam pupuh durma di atas berkaitan tentang tugas/ swadarma yang harus dilakukan oleh seorang pemimpin (Bupati). Secara tekstual, tembang macapat di atas menegaskan bahwa seorang Bupati yang diberikan amanat oleh rakyat untuk memimpin suatu daerah harus memiliki loyalitas dan dedikasi tinggi dalam bekerja. Selalu memperhatikan dan membantu kesusahan rakyat dengan memberikan dana punia (sumbangan) untuk kese- 
jahteraan bersama. Selain itu, seorang pemimpin (Bupati) harus selalu melakukan kewajiban beryadnya agar keseimbangan horizontal dan vertikal dapat tercapai. Konsep tentang kepemimpinan tertuang dalam ajaran Hindu yang disebut dengan Asta Brata Kepemimpinan (delapan koridor/ pedoman seorang pemimpin menjalankan amanat yang rakyat berikan). Dalam ajaran Asta Brata tersebut dengan tegas disampaikan bahwa seorang pemimpin harus mendahulu kepentingan rakyat daripada kepentingan personal. Parameter keberhasilan seorang pemimpin dapat dilihat dari indeks kebahagiaan masyarakat yang dimpimpinnya. Oleh karena itu, sasaran utama sebuah pemerintahan adalah menciptakan kesejahteraan dan kebahagiaan dari rakyat.

\section{Pupuh Smarandhana \\ Jroning manusa hirup, \\ dini di mretyabawana, \\ duang palih ya abahnya, pertama to Dewi Sampat, ane ngelah abah dewa, asuri sampat bwin bagus, ento agol keraksasan.}

Tembang macapat di atas berbicara tentang dua sifat bawaan yang dimiliki oleh manusia dalam kelahirannya di dunia. Dua sifat bawaan manusia ini satu sama salain sangat bertentangan, seperti putih dan hitam atau yang dikenal dengan istilah subha-asubha karma (perbuatan baik dan buruk). Sifat-sifat manusia tersebut adalah dewi sampat (sifat-sifat menyerupai dewa yang mendorong manusia berprilaku bijaksana, beretika, sopan santun, dan sebagainya) dan asuri sampat (sifat-sifat menyerupai raksasa yang mengarahkan manusia pada kehancuran). Segala perbuatan baik (subha karma) perlu dilakukan sedangkan perbuatan buruk (asubha karma) harus dihilangkan dalam diri agar mencapai ketentraman lahir bhatin. Sifat-sifat buruk yang berpotensi muncul dalam diri manusia harus $d i$ somya (netralisasi) agar dapat berubah menjadi sifat-sifat kedewataan (Dewi Sampat) sehingga tercapai kehidupan yang tentram dan bahagia. Proses somia (netralisasi) sifat-sifat Asuri Sampat agar menjadi sifat-sifat Dewi Sampat perlu dilakukan untuk menciptakan keseimbangan kehidupan dan alam semesta.

\section{Nilai Spiritualitas Tembang Macapat}

Spiritual merupakan sebuah nilai yang berkaitan dengan keyakinan manusia terhadap suatu kekuatan rohani yang bersifat immaterial. Nilai spiritual dalam kehidupan manusia dapat berfungsi sebagai pedoman perilaku secara konkret. Nilai spiritual ini cenderung berbentuk abstrak yang merupakan ide atau angan-angan manusia sesuai nilai-nilai yang religiustik. Nilai-nilai spriritual dalam tembang macapat masyarakat Bali berkaitan erat dengan hubungan manusia dengan Ida Shang Hyang Widhi (Tuhan Yang Maha Esa) yang bersifat suci dan sakral. Nilai spiritual yang dibicarakan sangat dekat dengan konteks ajaran agama Hindu Bali, misalnya tentang ajaran himsa karma, panca nyama bratha, sad ripu, catur paramitha, panca sradha. Dalam konteks sosio-kultural, nilai spiritual berhubungan dengan ideologi-ideologi yang dijadikan pedoman dan pandangan hidup oleh masyarakat Hindu Bali untuk mencapai keseimbangan hidup jasmani maupun rohani. Di bawah ini, disajikan data teks macapat disertai hasil analisis menggunakan teori nilai spiritual.

\section{Pupuh Ginanti \\ Ahimsa malu kawuwus, \\ solah tan memati-mati, \\ sahi mondong asih sayang, \\ marep ring sarwa maurip, \\ patuh sayange ring raga, \\ ento solah dharma jati.}

Tembang macapat di atas mengandung ajaran agama Hindu tentang ahimsa, yaitu sebuah ajaran yang melarang masyarakat Hindu Bali melakukan tindakan menyakiti apalagi membunuh sesama makhluk ciptaan tuhan. Pupuh Ginanti di atas memberikan petuah kepada manusia bahwa menyayangi sesama makhluk tuhan merupakan perbuatan dharma (kebenaran) sejati yang harus dilaksanakan sebagai wujud legetimasi ajaran agama Hindu. Kebahagiaan dan ketentraman sejati hanya bisa diperoleh bila manusia saling mencinta dan menyayangi sesama. Dalam Hindu, himsa karma sangat dilarang namun ada ketentuan khusus di mana himsa karma diperbolehkan, yakni himsa yang dilakukan guna kepentingan yadnya (dewa puja, atithi puja, dan pitra puja). Di samping itu, membunuh binatang perusak, nyamuk, bakteri penyebab penyakit, binatang yang mengancam nyawa manusia dibenarkan oleh ajaran dharma, tindakan tersebut disebut dengan dharma wighata. Membunuh musuh yang mengancam kedaulatan negara, membahayakan ibu pertiwi, nusa dan bangsa juga dibenarkan demi tegaknya ajaran dharma atau kebenaran di dunia.

\section{Pupuh Sinom \\ Nanak bagus pyanak bapa, \\ jalan lanturang ne jani, \\ kasilane kaping sanga, \\ Aharalaghawa pingit, \\ ane marti makirangin, minakadi pangan kinum, twara ngrapu kancan pangan, ne sinah ngawe gering, jroning kinum, ne ngawe punyah ejohang.}

Pupuh sinom di atas mengandung konsep Panca Nyama Brata, yaitu lima pengendalian diri dalam tataran mental/ pikiran untuk mencapai keseimbangan dan kesucian lahir bhatin. Secara spesifik konsep Panca Nyama Brata yang terkandung di dalam tembang macapat tersebut adalah konsep aharalaghawa, yaitu sikap pengendalian hawa 
nafsu untuk menghindari sifat rakus dalam diri. Tembang di atas sesungguhnya mengajarkan manusia untuk selalu mengendalikan pikiran dan hawa nafsu yang menjadi musuh utama penyebab kemunculan kesengsaraan. Tersirat secara tekstual bahwa salah satu tahapan terendah tentang pengendalian hawa nafsu yang bisa manusia lakukan adalah menahan diri untuk memakan makanan yang dapat menimbulkan penyakit dan memabukan. Memiliki sifat rakus dengan memakan segala makanan yang tidak sukla dan mengandung bibit penyakit dapat merusak diri sendiri. Bila tubuh mulai sakit dan rusak akibat sifat haralaghawa (rakus), maka manusia tidak dapat menjalankan aktivitas/ swadharmanya. Menjaga kesehatan jasmani dan memproteksi diri terhadap makanan yang mengandung bibit penyakit dapat dikatakan bagian dari spiritualitas manusia yang berlandaskan ajaran dharma, sebab secara tidak langsung manusia telah merawat rumah persemayaman tuhan (atmam) dalam tubuh mereka sendiri.

\section{Pupuh Adri}

I Sadripu ngawitin ya tumbuh,

di bhuwana manah,

ditu mentik dadi bibit,

ngawe gering agung,

I manusa mangde durus,

lali maring shang hyang atma,

katuduh mangde manyurat,

maring suka kabhudayan,

sane matanggu sangsara.

Secara tekstual tembang macapat di atas menyatakan bahwa Sadripu yang dibiarkan tumbuh dalam alam pikiran akan berkembang menjadi bibit penyakit dan menyebabkan manusia terjerumus ke dalam kegelapan. Manusia yang sudah terjerumus ke dalam kegelapan akan melupakan ajaran-ajaran dharma sehingga menyebabkan kesengsaraan berkepanjangan dalam kehidupan. Sad Ripu merupakan ajaran agama hindu yang memiliki pengertian bahwa manusia memiliki musuh dalam diri yang bila tidak dikendalikan akan membawa kesengsaraan sekala dan niskala. Musuh manusia itu terdiri atas enam bagian yaitu, kama (hawa nafsu/ keinginan negatif), lobha (rakus/tamak), krodha (kemarahan), moha (kebingungan yang membuat gelap mata), mada (mabuk), dan matsarya (dengki/ iri hati). Kebahagiaan dan kedamaian diri dapat tercapai bergantung cara mereka mengendalikan keenam musuh yang terdapat dalam diri mereka. Tembang macapat di atas, secara implisit menegaskan bahwa pengendalian keenam musuh dalam diri sangat bergantung dari kemampuan manusia mengelola mental dan pikiran mereka. Sebab, keenam musuh manusia itu dapat berkembang menjadi penyakit bila ia tertanam kuat dalam pikiran. Jadi, kunci kebahagian dan ketentraman manusia menurut ajaran Hindu sesungguhnya bersumber dari alam pikiran mereka sendiri.

\section{SIMPULAN}

Macapat sebagai suatu karya sastra yang artistik secara konseptual dapat dijadikan landasan bersikap, baik bagi kebutuhan personal maupun kolektif guna terwujudnya karakter positif masyarakat Bali. Nilai-nilai didaktis yang terkandung dalam tembang macapat, di antaranya adalah kejujuran, kedisiplinan, kerja keras, bertanggung jawab, dan kasih sayang.

Nilai humanistis dalam tembang macapat masyarakat Bali berkaitan erat dengan kehidupan manusia secara sosial. Nilai humanisme ini dianut oleh manusia mengenai apa yang dianggap baik dan apa yang dianggap buruk. Tembang-tembang macapat sebagai suatu karya sastra yang berakar dari sosio-kultural masyarakat Bali memberikan pelajaran yang luhur tentang nilai-nilai kemanusiaan. Macapat merupakan penafsiran dan representasi pemikiran/ idealisasi pengarang dan cerminan pengolahan realita kehidupan yang dialami oleh pengarang dan masyarakat Bali secara umum. Nilai-nilai humanistis yang diperoleh dari hasil analisis tembang macapat adalah kekeluargaan/ persaudaraan, kerukunan, gotong-royong/tatwam asi, dan bhineka tunggal ika.

Nilai-nilai spriritual dalam tembang macapat masyarakat Bali berkaitan erat dengan hubungan manusia dengan Ida Shang Hyang Widhi (Tuhan Yang Maha Esa) yang bersifat suci dan sakral. Nilai spiritual yang dibicarakan sangat dekat dengan konteks ajaran agama Hindu Bali, misalnya tentang ajaran himsa karma, panca nyama bratha, sad ripu, catur paramitha, panca sradha. Dalam konteks sosio-kultural, nilai spiritual berhubungan dengan ideologi-ideologi yang dijadikan pedoman dan pandangan hidup oleh masyarakat Hindu Bali untuk mencapai keseimbangan hidup jasmani maupun rohani.

\section{Saran}

Sehubungan dengan simpulan di atas, disarankan beberapa hal sebagai berikut:

Pemerintah harus mengupayakan pelestarian kesenian tradisional macapat yang merupakan kesenian khas daerah Bali dengan melakukan sosialisasi kepada masyarakat, khususnya anak-anak muda bahwa kesenian macapat selain sebagai sebuah seni pertunjukkan olah suara tetapi juga dapat digunakan sebagai media pendidikan, agama, dan sosial/ pergaulan.

Para praktisi seni macapat di Bali harus membangkitkan kesadaran bahwa kesenian macapat tidak hanya cukup untuk dilantunkan sebagai media pelipur lara dan pemenuhan kebutuhan individual semata, melainkan perlu juga diresapi, dihayati, dan dipahami secara mendalam makna dan nilai-nilai yang terkandung di dalamnya. Dengan demikian, eksistensi kesenian macapat akan semakin menggeliat ke permukaan di tengah-tengah lesunya peminat kalangan pemuda di era modern saat ini. 
Pendidikan karakter merupakan salah satu anjuran pemerintah kepada para guru/ pendidik dalam rangka membangun budi pakerti/ akhlak yang mulia dalam diri peserta didik dengan tujuan menciptakan bangsa yang bermartabat. Berkaitan dengan hal tersebut, para guru, khususnya guru bahasa daerah harus menyediakan sumber atau referensi dalam rangka menanamkan nilai-nilai luhur, seperti nilai didaktis, humanistis, dan spiritual yang terkandung di dalam keseniaan macapat kepada para peserta didik.

Kesadaran kaum pemuda di Bali tentang kesenian macapat harus ditumbuhkan sedini mungkin bahwa kesenian macapat bukanlah sekadar aktivitas bernyanyi/ metembang semata, lebih daripada itu kesenian macapat memiliki manfaat dan nilai-nilai pendidikan yang sangat tinggi, baik berupa nasihat-nasihat, ajakan ataupun anjuran yang tentunya bersifat positif.

\section{DAFTAR RUJUKAN}

Endaswara, Suwardi. 2008. Metodologi Penelitian Psikologi Sastra. Yogyakarta: Media Pressindo.

2017. Etnoideologis: Antara Bulan, Gunting, dan Jarum. Makalah (Disampaikan dalam Seminar Nasional "Sastra Multikultural: Merayakan Keberagaman, Merawat Ke-Indonesiaan FPBS IKIP PGRI Bali).

Kattsof, Louis. 2004. Pengantar Filsafat. Terjemahan Soejono Soemargono. Yogyakarta: Tiara Wacana Yogya.

Luxemburg, Van Jan, Miekel Ball, \& Willem G. Weststeijn. 1987. Over Literatur. Terjemahan Akhadiati Ikram. 1991. Tentang Sastra. Jakarta: Intermasa.

Matthew, Milles. 1992. Analisis Data Kualitatif. Terjemahan Tjetjep Rohendi Rohidi. Bandung: PT Remaja Rosdakarya.

Moehanto, Budhy. 1987. Tuntunan Sekar Macapat. Pemalang: CV Mitra Utama.

Nurgiyantoro, Burhan. 2007. Penilaian dalam Pengajaran Bahasa dan Sastra. Yogyakarta: BPFE.

Pradopo, Djoko. 2013. Beberapa Teori Sastra, Metode Kritik, dan Penerapannya. Yogyakarta: Pustaka Pelajar.

Ratna, I Nyoman Kutha. 2005. Sastra dan Cultural Studies (Representasi Fiksi dan Fakta). Yogyakarta: Pustaka Pelajar.

2009. Teori, Metode, dan Teknik Penelitian Sastra. Yogyakarta: Pustaka Pelajar.

Saifullah, Ali. 2004. Antara Filsafat dan Pendidikan. Surabaya: Usaha Offset Printing.
Story, Jhon. 2003. Teori Budaya dan Budaya Pop. Yogyakarta.Qalam.

Suarta, I Made dan I Kadek Adhi Dwipayana. 2014. Teori Sastra. Jakarta: PT Raja Grafindo Persada.

Sugihastuti. 2002. Teori dan Apresiasi Sastra. Yogyakarta: Pustaka Pelajar.

Swingewood, Alan dan Diana Lawrenson. 1972. The Sociology of Literature. London: Paladin.

Wellek, Rene \& Austin Warren. 1977. Theory of Literature. Terjemahan Melani Budianta. 2014. Teori Kesusastraan. Jakarta: Pustaka Utama.

Yasa, I Nyoman. 2012. Teori Sastra dan Penerapannya. Bandung: Karya Ahimsa Darwati. 